and water draining an area in which post-Caledonian granite has intruded the Eleonore Bay Group. The stream sediment samples collected this year also show high contents of uranium, but no mineralisations were found duríng the field work.

\title{
References
}

Nielsen, B. L. \& Larsen, H. C. 1974: Airborne geophysical survey in central East Greenland. Rapp. Grønlands geol. Unders. 65, 73-76.

Nielsen, B. L. \& Steenfelt, A. 1975: Prospecting for uranium in central East Greenland. Rapp. Gronlands geol. Unders. 75, 107-110.

\section{Uraniferous hydrocarbons (carburan) associated with Devonian acid volcanic rocks, Randbøldal, northern East Greenland}

\author{
Karsten Secher, Bjarne Leth Nielsen and Agnete Steenfelt
}

Uranium mineralisations were discovered in acid volcanic rocks in Randbøldal, Gauss Halvø, during field work in 1974 following an airborne radiometric survey (Nielsen \& Steenfelt, 1975). The geology of the area has been described by Bütler (1954), Graeter (1957) and Alexander-Marrack \& Friend (1976).

\section{Field description}

Uranium occurs in the lower volcanic member of the Kap Franklin series of Middle Devonian age. Quartz porphyritic rhyolites and pyroclastic rocks are intercalated with continental sedimentary formations which represent the molasse of the main Caledonian orogeny. Among the major radioactive constituents, only carburan has so far been identified in the rhyolites and tuffaceous breccias. The mineralisations are located within an area of about $1 \mathrm{~km}^{2}$, and the individual outcrops of high radioactivity cannot usually be followed for more than $20 \mathrm{~m}$. The mineralisations are often found close to the boundary of an overlying pyroclastic unit.

The carburan has three principal modes of occurrence:

(1) in joints, veinlets and along grain boundaries,

(2) as isolated globular or amoeboidal grains with diameter in the range $1-5 \mathrm{~mm}$,

(3) disseminated or sometimes as clusters, with individual grain sizes usually less than 1 $\mathrm{mm}$.

Fig. 35 illustrates an autoradiography showing the distribution of radioactive compounds in occurrence of types 1 and 3 in a quartz porphyritic rhyolite. The orbicular quartz 


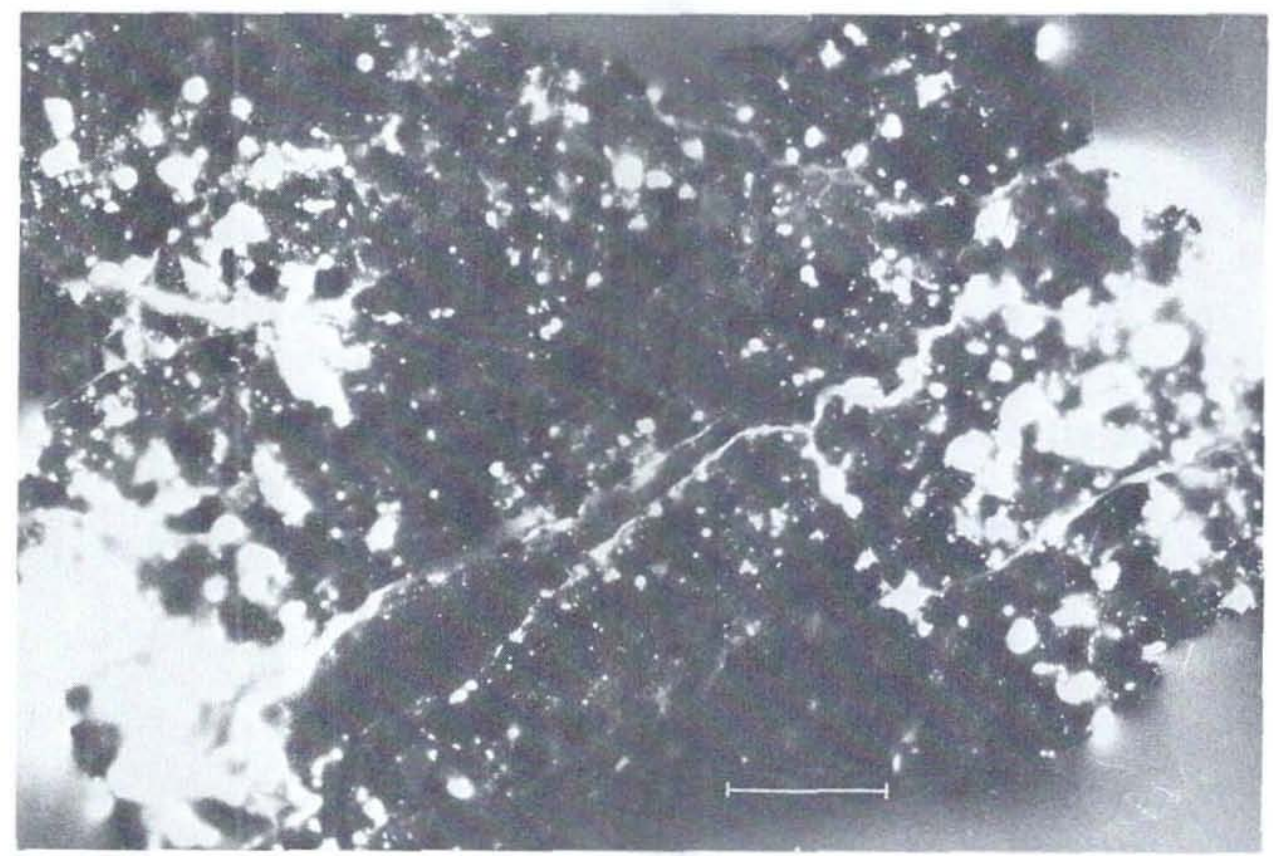

Fig. 35. Autoradiograph of porphyritic rhyolite. Radioactive compounds (white) are seen in veinlets, disseminated and as clusters. Orbicular quartz phenocrysts are black. The $U$ and Th content of the sample is about $1450 \mathrm{ppm}$ and $35 \mathrm{ppm}$ respectively. Scale $=2.0 \mathrm{~cm}$. GGU sample no. 132627 , Randbøldal, northern East Greenland.

phenocrysts appear as completely black spots. In general the rhyolites are strongly altered and oxidised. The uranium contents of the mineralised rhyolites are in the order of 500-1500 ppm; the thorium content averages $30 \mathrm{ppm}$.

It is noteworthy that non-uraniferous carbonaceous matter has also been found at several localities in the adjacent Devonian and Carboniferous sedimentary formations.

\section{Physical and chemical properties}

Uraniferous hydrocarbon is by many authors designated thucholite (from Th-U-C-H-O-lite) as suggested by Ellsworth (1928). However, the present authors prefer the name carburan as the Th content in the Randbøldal material is negligible. Carburan is a complex mixture of uranium-bearing hydrocarbons. It has a friable character and conchoidal fracture. Its hardness is between $2-3$ and its specific gravity is about 1.5 . The colour is black and the material has a pitchy lustre.

The carburan was recognised and examined in reflected light. A few varieties were distinguished, and they are generally shades of grey to grey-brown, with a weak bireflectance and a strong mottled anisotropy. Reflectivity at $590 \mathrm{~nm}$ is in the range $8.7-10.2 \%$.

Analysis carried out on separated carburan grains showed a uranium content of $5.5 \%$. 
Thorium is not present in detectable quantities. Emission spectrography with DC-arc exitation, laser exitation, and electron microprobe investigations showed that $\mathrm{Ca}$ and $\mathrm{Ti}$ are also major components. Important trace elements are $\mathrm{Al}, \mathrm{Fe}, \mathrm{Cu}, \mathrm{Pb}, \mathrm{Zn}, \mathrm{As}, \mathrm{Y}, \mathrm{Zr}, \mathrm{Nb}$ and Be.

\section{Mineralogy}

The carburan from the acid volcanics in Randbøldal varies in apperance and three characteristic types can be recognised. The first type is characterised by inclusions of sulphides, mainly pyrite which are often central in the grain (fig. 36). The second type contains inclusions of Ti-rich matter ('leucoxene'), which together with fine-grained silicates, give the carburan a turbid appearance. Locally a 'swimming-apart' texture is displayed, in which angular grains of 'leucoxene' occur as islands in the carburan. The third type is homogeneous and without inclusions. The three types were observed in each of the three types of field occurrence (see above).

Fission track examination has shown that the distribution of uranium within the carburan is uniform in most cases. This differs from carburan described from the Witwatersrand, where the uranium is restricted to remnants of uraninite within the hydrocarbon (Schidlowski, 1966).

The other minerals present in association with the carburan are principally metallic sulphides and iron hydroxides. Pyrite is the most abundant, and pyrrhotite, chalcopyrite, covellite, galena and sphalerite occur sporadically. Limonite is quite common as an alteration product of the sulphides and in several instances the limonite contains uranium. Another uranium mineral (not yet determined) in the Randbøldal volcanics is seen from X-ray

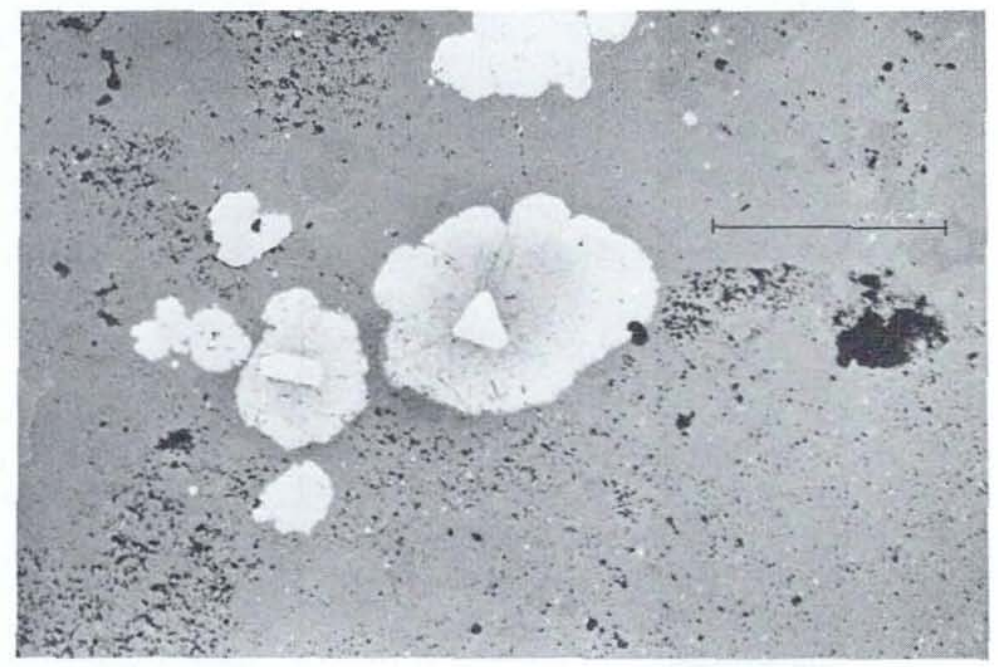

Fig. 36. Inclusions of pyrite (white) in carburan globules (grey to white) surrounded by silicates (grey to dark grey). Reflected light, one polar. Scale $=0.5 \mathrm{~cm}$. GGU sample no. 132655, Randbøldal, northern East Greenland. 
examinations to be completely replaced by limonite. In addition, hydrocarbon material (solid bitumen) without any content of uranium was found in a few specimens. The carburan was not attacked by weathering as were most of the other minerals examined. However, secondary uranium minerals have been observed, although not in contact with hydrocarbons. Among these, wölsendorfite seems to be common.

\section{Conclusions}

Uraniferous hydrocarbon is reported from several localities all over the world, in different environments and ranging in age from Precambrian to Tertiary. However, as far as the present authors can determine, carburan has never been reported from acid volcanics, and as carburan is usually associated with uraninite it appears that the Randbøldal carburan is a rather unusual kind. At the present stage of investigation it is believed, that primary uranium in the acid volcanics was mobilised during alteration processes. The presence of carbonaceous matter in Randbøldal and its vicinity suggests that hydrocarbons were able to migrate into the rocks. This indicates that favourable catchment environments for uranium could have formed not only in the acid volcanics, but also in the surrounding sediments. Carbonaceous matter has probably controlled the redeposition of a part of the uranium whereas another part was caught by the limonite. During the deposition of carburan, pyrite and Ti-minerals seem to be important in localising the uraniferous hydrocarbon. Nonuraniferous equivalents occur where the quantity of uranium was insufficient for the formation of carburan and uraniferous limonite.

\section{References}

Alexander-Marrack, P. D. \& Friend, P. F. 1976: Devonian sediments of East Greenland, the eastern sequence. III. Meddr Grønland 206,3.

Bütler, H. 1954: Die stratigraphische Gliederung der Mitteldevonischen Serien im Gebiete von Kap Franklin am Kejser Franz Josephs Fjord in Zentral-Ostgrönland. Meddr Grønland 116,7,1-126.

Ellsworth, H. V. 1928: Thucholite, a remarkable primary carbon mineral from the vicinity of Parry Sound, Ontario. Amer. Miner. 13, 419-439 \& 439-441.

Graeter, P. 1957: Die sauren Devonischen Eruptivgesteine des Kap Franklingebiets am Kejser Franz Josephs Fjord in Zentral-Ostgrönland. Meddr Gronland 155,3, 1-102.

Nielsen, B. L. \& Steenfelt, A. 1975: Prospecting for uranium in central East Greenland. Rapp. Grønlands geol. Unders. 75, 107-110.

Schidlowski, M. 1966: Beiträge zur Kenntnis der radioaktiven Bestandteile der WitwatersrandKonglomerate, III Kohlige Substanz ("Thucholith"). Neues Jb. Mineral., Abh. 106, 55-71. 